\title{
IX. On the ancient names for colour, particularly as applied to the colour of the light of stars
}

\section{T. Forster Esq.}

To cite this article: T. Forster Esq. (1817) IX. On the ancient names for colour, particularly as applied to the colour of the light of stars, Philosophical Magazine Series 1, 49:225, 49-55, DOI: 10.1080/14786441708637832

To link to this article: http://dx.doi.org/10.1080/14786441708637832

里 Published online: 27 Jul 2009.

Submit your article to this journal $₫$

Џ Article views: 3

Q View related articles 5 
24. Smalt from the King of France's porcelain manufactory at Sevres fused into a mass, and resigned its colour.

25. The Opal decrepitated violently.

26. The CancedoNy from Iceland fused with intense light into a fine white frothy enamel.

I have thus selected a few of what I cousider the most interesting experiments, and shall be happy in resuming my account of further trials.

Before this instrument the most unyielding bodies forgo their powers of cohesion, and enter into rapid fusion. Its energy of temperature is described in one of the lines of Pope-for before it

"Rocks fall to dust, and mountains melt away."

In the course of our experiments we have met with no sulsiance sufficiently refractory to resist its intensity of ignition. Some of these experiments have been detailed by Dr. Clarke; but I deemed it best to submit an unbroken series : and such of them as have been described by Professor Clarke will find a full corroboration in our repetition. We are even now only upon the threshold of discovery. The rays of chemical science are bounded by no horizon :-mightier wonders remain to be revealed.

I am, with very great respect, sir, Your obliged and faithful servant,

London, Jamuàry $20,1817$.

J. Murray.

P.S. Two Emeralds were fused into ONE MASS, exhibiting, during fusion, a light too vivid for the eye to endure without suffering. The beautiful globule thence obtained had become limpid and colourless, with the exception of a band or zone of enamel, like a horizon, circling the spherical mass. The specimen is in possession of Geo. Rennie, Esq. who, as well as in the other experiments, joined me in this.

IX: On the ancient Names for Colour, particularly as applied to the Colnur of the Light of Stars. By T. Forster, Esq.

\section{To Mr. Tilloch.}

Sir, $-H_{\text {AvING lately met with several treatises on the mu- }}$ tations of colour in the light of the fixed stars, in which this fact has been attempted to be proved by citations from the works of the ancient poets and others, who have described the colour of particular stars now evidently not answering the same description; and having myself made some observations on the colour of stars, 1 was led to refer back to the ancient auVol. 49. No, 225. Jan. 1817. D thorities 
thorities themselves, and was consequently induced thereby to enter more at large into the real import of the names used by the Roman and Greek writers for colours. And I am convinced that no accurate argument can be drawn from the Classical writers respecting the real colours of stars, or any other uatural bodies, from the very vague and indefinite meaning of the names of colours themselves, and also from the excessive latitude given by poetic writers to the signification of words. I would, however, make an exception of such cases as those wherein two particular colours are contrasted to each other in the same passage.

To apply this observation to our subject: Though the observations of Tycho Brahe, and other more modern astronomers, relative to the light of the stars, are valuable, being written at a time when, philosophical Latin having become the medium of communicating science, terms were used in a more definite sense; yet I should suspect the accuracy of any arguments drawn from the early Greek and Roman poets, in which the colour of the starlight is alluded to; making an exception only of such passages as coutrasted strikingly opposite colours.

I shall offer a few examples to illustrate this position; and conclude with referring to the etymological import of many words designating colours.

I. Passnges wherein two or more colours are contrasted and distinguished, but which still do not accurately define the precise lint.

The ancients have in some instances used words for colour in a sense hardly to be mistaken, by employing them to contrast two phenomena whose difference of colour is marked and well known everywhere, and which we have no reason to think changes from time to time. Instances are to be met with, in which the colours produced by refraction of the light of the heavenly bodies constitute examples.

Ovid, in Metamorph. xv. 192, uses rubere, to redden, for the red colour of the sun near the horizon, produced by denser refraction; and contrasts it with the term candidus, applied to the sun in his greatest altitude ; whereas from a lesser degree of refraction it approaches nearer to white. Thus,

"Ipse Dei clypeus, terrâ cum tollitur imâ, Mane rubet : terrâque rubet, cum conditur imâ,

Candidus in summo est. Melior natura quòd illic

Eetheris est, terreque procul contagia vitat."

Virgil, in Georg. i. 431, among the signs of wind, evidently marks the red colour of the moon:

"At, sivirgincum suffuderit ore ruborem,

Ventus erit : vento scmper rubet aurea Phobe." 
He shortly afterwards contrasts this red colour with pura, or white, that is free from coloration, when, before fine weather, the moon,

"Pura, neque obtusis per crelum comibus ibit."

Horace has the same expression for the pure light of the moon, in Carm. ii. v. 20.

$$
\begin{gathered}
\text { "Ut pura nocturno renidet } \\
\text { Luna mari." }
\end{gathered}
$$

Aratus also, in Dios. 53, evidently contrasts the red with the white colour, in the following lines on the presages of weather:

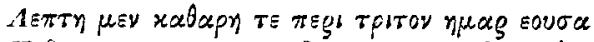

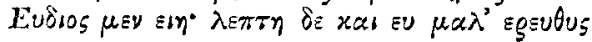

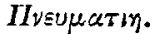

Again, speaking of the more certain prognostic of rain in proportion as the circles called halos are more reddened;-a fuct well known to modern meteorologists,-he says :

$$
\begin{aligned}
& \text {....... }
\end{aligned}
$$

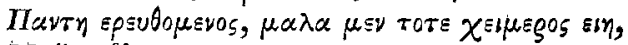

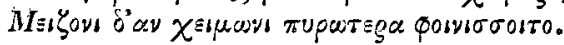

Theophrastus, in Sign. Temp. contrasts the blackish colour of the stum and moon, by the interposition of an obscure cloud, as a sign of rain, with the red colour which is a forerunner of wind.

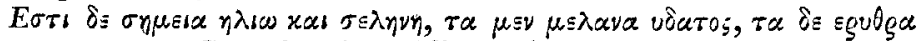
туечнатоs. Consult also Plin. Hisl. Nat. xviii. 35. The learned Scapula in Lex. Gr. observes of the word $\mu \_\lambda \alpha$, black: vox sape pro horrendo aut obscuro posita, quia talia sunt atra*. Thus the confused or the black appearance might constitute the contrast to the red one, as above cited.

II. Passages wherein a most extended and undefinable signification is given to the names of colours by the ancients.

A proof of the very indefinite import of names for colours among the ancients may be drawn, lst, from their incongruity with the known colours of the substances to which they are applied, if taken in the strict sense: and 2dly, from examples in which the same term is applied to bodies of a known difference of colour.A few examples will suffice, which happen to be in my mind, and will lead to a more extensive inquiry.

Purpureus is applied,

1. To the rose, in which it approaches the nearest to our modern idea of purple;-thus in Virgil, c. 14.

$$
\text { "Rosa purpurea." }
$$

* If the reader wishes to pursue this subject further, I have put a long list of references in the notes to a late edition of the Diosemeia of Aratus, p. 11, and sequel. 


\section{On the ancient Names for Colour, particularly}

2. To the colour of the violet; as in Virg. Georg. iii.

"Violæ sublucet purpura nigræ."

3. To the narcissus, as in Virg. Ecl. v. 38.

"Pro molli viola, pro purpureo narcisso."

4. To the colour of the sea, as in Virg. Georg. iv. 373,speaking of the Po, or Eridanus :

" - quo non per pinguia culta

In mare purpureum violentior influit. amnis."

5. To the colour which is given to the green waves of the sea (virides unda) by the rough wind; as

"Spiritus Eurorum virides quum purpurat undas."

In which case purpurat may mean, lst, that it gives the sea that purple colour sometimes occurring in storms ; or, $2 \mathrm{dly}$, that it causes the brilliant white or silver colour of the frothy spumes of the rough waves in the sun: the last sense is most likely, as purple is applied.

6. To the brilliancy of the sun and other luminous bodies in general; as

"Purpureos inter soles, et candida Lunæ Sydera."

The word moøqugeos has in Greek a signification almost as unlimited.

7. To flowers in general, as if it signified only brilliancy, from the gaudy contrast of flowers to their leaves.

Candidus is 'applied,

1. To things fair or beautiful in the most general acceptation, as to the constellation Taurus.

"Candidus auratis aperit cum cornibus annum,

Taurus," \&c._Virg. Geors.

2. 'To the sun when high, either from its brightness or whiteness in comparison with his disk in a horizontal position,

"Candidus in summo est," \&c.___Orid.

Also, Solis candor frequently for the sun's bright light.

The word comes from candeo, to shine, and has no limited meaning, as to colour, whatever.

The word Caruleus seems to have been derived from roilos. It is applied,

1. To the snake, perhaps from the blue colour of some particular snake.

2. To the sea-Corrula verrunt (remigio). See also many passages wherein the ocean seems to be called cceruleus, viridis, and purpureus, almost indifferently, as it ae- 
accorded with versification in poetry, or avoided tautology. -I may add, that Albus is the most restricted in its signification. Niger as extended as any. Argenteus and Aureus are again more limited in their meaning, as are in general the colours taken from metals.

Flavus is put,

1. For red hair, as flava Minerva, \&c.

2. For many flowers of different colours, for crimson, \&c. And numerous other substances might be added, were it not for swelling this paper.

Ruber is applied variously:

1. To the hyacinth *, as Virg. Eclog.

"Suave ruhens hyacinthus."

2. To the red colour of the heavenly bodies before wind, as above quoted:

"Vento mbet auren Phoebe," \&c.

3. To the moon itself, although her colour is so often contrasted with red, and called pallida, alba, candida, \&c.; consequently camnot ever be depended on as representing' the red colour of any fixed star, called by the ancients rubra.

Festus Avienus in the Anthol. Vet. Lat. says,

$$
\begin{aligned}
& \text { ". . . . reparatum Cyuthia format } \\
& \text { Licis ionore jubar, curvatis comibus arcus } \\
& \text { Quod de fratre rubet." }
\end{aligned}
$$

There are so many other instances where rubere is put for mitere, splemdescere, \&c. that I am convinced no argument can be drawn from its application to the light of stars by ancient poets. An ingenious paper on this subject, however, has been inserted in the Philosophical Transactions by Mr. Barker; but from an examination of the subject among the ancient writers, too long to be inserted in full here, $I$ am induced to rely much less than he does on the particular signification of the ancient terms for colour.

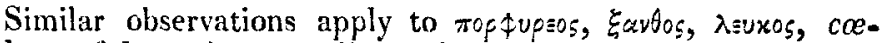
ruleus, fulvus, luteus, allus, niger, \&c.; and to the words for colours in other languages. In short, in the progress of science, while literature was emerging fron the dark ages, the names of colours, like other words, were derived from reference to particular coloured bodies: but as there were

* It is not quite certain what flowers the Hyacinth and Narcissus of the ancients were. Our present narcissus has no properties from which it could be derived, as it evidently is from veazsw. 
not names enough to express all the tints of nature, their signification was widely extended, particularly by the license of the ancient poets; and it is only by modern philosopher's, as science advanced, that they have become more determined in their signification.

In a former paper in the Philosophical Magazine* I have given a series of the etymological derivations of the names for colours in our language, where by reference to old books, and by the facility of etymology, in English, we can trace them to their primitive meaning in the mother tongue; and 1 have proposed a new Nomenclature for colours, which shall express the proportion of primitive colours which compose the beautiful and extensively varied tints by which the surface of the globe is everywhere ornamented. Aud I have added these observations, on the application of the names for colour to the illustration of change of colours of the fixed stars, with a view that those who have more classical

\footnotetext{
* See Phil. Mag. Nov. 1813, vol. xlii. p. 327; also for Aug. 1313, vol. xlii. p. 119.

YELLOW,-This word is derived from the Anglo-Saxon verb zerelzan, accendere (to inflame, and signifies the colour of fame. In like manner

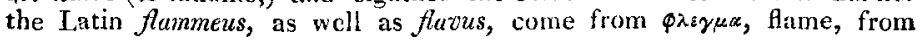

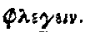

RED.-The etymology of the word seems dountful. Horne Tooke has omitted it in his etymological account of colsurs in the Diversions of Purley. I suspect, however, it may have some connection with the word ray, and expresses the colour of the sun's ravs.

Buve.- This word seems to come from blopan, florere (to blow as a floiver does), and significs the colour of flowers;-certainly the most indetinite of all our names for colours, like the Greek yoydos, frum is and avdos, i, e. color e floribus.
}

GREEN is derived from the Anglo-Saxon verb gpennan, zircscere. In like manner the Latin virere gave the adjective viridis.

PuRPle is commonly used in moderu times for the componnd of red and blue, is derived from the Latin purpureus, and signifies only flame coloured; from $\pi \tilde{u} \rho$, five.

Brows is a corruption of the past participle of the Anglo-Saxon verb bnennan, urere (to bum), and signifies the colour of burat substances; having etymologically no distinction between it and ash colom. In like manner the Latin, fuscus comes from pwostw, ustulare, as noticed by Tooke; and has the same real meaning, as well as the same application, at brown. Query, Whence come fulous and aquilus?

Write comes from the Moso Gothick $\odot A \psi G N N$, spumare. Our word Gmy is derived from zenezulan, inficere, meaning the colour of tainted, infused, or damaged articles, and is most properly used when applied to mixtures, which appear as if tainted or tinged with foreign colours, as the salt and pepper mixtures, \&c.

The dilutions of yellow by white are called straw colour.

BuACK has probably the sane root as "bleak," perbaps from blæcan, and signifies deprived of colour. 
wading and opportunities of investigation, may see one source from whence we can detect the fallacious evidenee of the old poetic writings in matters of philosophy.

I am, sir, yours, \&c.

Clapton, Dec. 9, 1816.

Thomas Forster.

$\mathrm{X}$. Combination of the Electric Column, the Thermometer, Barometer, and Hygrometer in one Instrument, for Electroatmospherical Researches. By A ConkesponDenT.

To Mr. Tilloch.

$S_{I R},-T_{H E}$ electric column of De Luc promises to be not only an interesting but also a useful apparatus, as its powers seem to be influenced by the electrical state of the atmosphere. It has occurred to me, that a combination which would at one view give all the different states of the atmosphere, would be very convenient in electro-atmospherical researches. If you should consider the following worthy a place aniong your more important communications, it is mueh at your service.

$$
\text { Yours, \&c. }
$$

D.

I trust the plan will not require much explanation. It may be sufficient to say that $A$ (Plate I. fig. 6 ) is a powerful colums insulated on Mr.Singer's plan; C, a thermometer; and B, a barometer, which should have a brass or an ivory index with a gilt wire to form a communication with the bottom of the column; the parts EF may be covered with sealing-wax; $G$ may be a small figure or a glass tabe; $D$ is the index of a catgut hygrometer stretched on small pulleys on the bottom of the stand, as is represented by $\mathrm{H}-\mathrm{I}$ (fig. 7 and $\mathrm{S}$.)

XI. Mr. Farey's Correction of his Remarks in our last Number, regarding a Geologist leing attached to the Government Trigonometrical Establistiment.

\section{To Mr. Tilloch.}

Sir, - Evident justice to the Parties who direct the Government Trigonometrical Survey of our Island, carrying on under the Board of Ordnance, and toward a highly respectable and able Mineralogist and Geological Investigator (the President this year of the Geological Society) requires of me, without delay, to $\mathrm{D}_{4}$ apologize 